\title{
A tough ruling for medical device manufacturers
}

The stock prices of some medical device makers tumbled in late June as Wall Street reacted to a US Supreme Court ruling that held that federal laws regulating medical devices do not necessarily shield manufacturers from product liability lawsuits brought at the state level. Industry officials fear that the high court's ruling will open the floodgates to personal injury claims against the makers of many medical devices (from pacemakers and prosthetic heart valves to breast implants and hip replacements) and will affect the long-term health of the domestic medical device industry.

'The court's ruling was issued in the case of a Hlorida woman, Lora Lohr, who, in 1987, was fitted with a pacemaker made by Medtronic, Inc., a medical device manufacturer located in Minneapolis, Minnesota. The device was equipped with Medtronic's Model 4011 pacemaker lead, which transmits the electrical signal from the pulse generator to the heart. The lead was approved in 1982 by the US Food and Drug Administration (FDA) under the Medical Device Amendments Act of 1976 through the "premarket notification" or $510(\mathrm{k})$ process (a process designed to allow companies manufacturing "me-too" versions of products already available to enter the market more quickly.)

Three years after the pacemaker was implanted, Lohr underwent emergency surgery when the device failed, allegedly owing to a defect in the pacemaker lead. In 1993, Lohr and her husband sued Medtronic for damages in a Florida state court on the grounds that the pacemaker lead had a defective design, that Medtronic had failed to exercise reasonable care in the manufacture, assembly and sale of the pacemaker and that it had failed to warn of possible safety concerns.

Medtronic argued that, under the 1976 Act, states may not set "requirements" (standards) that differ from or add to federal requirements. However, all nine Supreme Court justices agreed that the Lohrs' negligent design claim was not preempted by the federal statute. "The States' historic police powers cannot be superseded by a Federal Act unless that is Congress' clear and manifest purpose," wrote Justice John Paul Stevens in delivering the Court's opinion. Stevens and several other justices also said Medtronic's argument is not only "un- persuasive, it is implausible," because it would "grant complete immunity from design defect liability to an entire industry that, in Congress' judgment, needed more stringent regulation."

The Court's ruling now clears the way for the Lohr case to proceed in the Florida state court.

The Supreme Court's ruling does not appear to

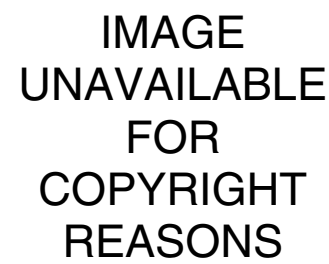

An allegedly defective pacemaker lead made by Medtronic led to a state lawsuit and the Supreme Court. nificant, because an overwhelming number of new medical devices (such as Medtronic's pacemaker lead) are apE proved through the $510(\mathrm{k})$ rather than the PMA process. For example, in fiscal year 1995, FDA granted nearly eight thousand $510(\mathrm{k})$ applications and a mere 27 PMAs.

For Medtronic, the extend to medical devices approved by FDA through its more rigorous "premarket approval" (PMA) process. This level of review is required for "brand-new" types of devices, the malfunction of which could cause serious adverse health consequences, or even death.

Even so, the impact of the ruling on the industry as a whole could still be sig- ruling is likely to have only a "slight" impact, according to company spokesperson Dick Reid. However, Reid concedes that the cost of defending the lawsuits now facing the company is certainly going to rise as more of them go to trial: "That is where the cash register really starts ringing."

DIANE GERSHON

\section{Banking on safe blood}

The risk of contracting a viral infection from a blood transfusion can never be eliminated, but it is very low, according to a recent study sponsored by the US National Heart, Lung and Blood Institute (NHLBI). The Retrovirus Epidemiology Donor Study (REDS) evaluated the risk of transfusion-transmitted infection with four notorious blood-borne viruses: HIV, human T-cell lymphotropic virus, and the hepatitis $B$ and $C$ viruses.

"The results are very reassuring," says Paul Holland of the Sacramento Medical Foundation Blood Center. "We now have good proof that the risk of infection from transfusion of blood infected with any of these four viruses is incredibly small."

For example, the study reports that the risk of an HIV-contaminated blood donation entering the donor blood supply is 2 cases per million donations. REDS is also the first study to assess the total risk of contamination by any of the four viruses (1 per 34,000 units of blood).

The study, published in June in the New England Journal of Medicine, also demonstrates "dramatic improvement in the safety of the blood supply compared to a decade ago," says George Schreiber of Westat Incorporated.

Michael Busch of Irwin Memorial Blood

\section{IMAGE UNAVAILABLE FOR COPYRIGHT REASONS}

Advertising for blood in 1946.

Centers in San Francisco, a coauthor of the study, says the study also provides "an accurate mechanism for ongoing surveillance of risk in the blood supply."

However, the real importance of the REDS study may be in providing "an accurate assessment of 'window period' blood donations,"says Elaine Sloand, assistant to the director of NHLBI. (The 'window period' is the time during which a donor is infected but has insufficient antibodies for detection by conventional tests.)

Although REDS is scheduled to end in 1998, NHLBI has appealed for extra funding to support the study's continuation. "The large repository of REDS serum samples is invaluable," says Sloand.

ORLA SMITH 